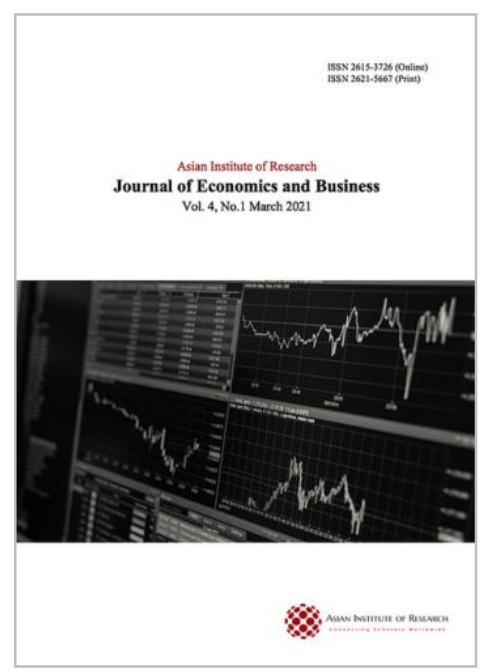

\title{
Journal of Economics
} and Business

Jekelle, Helen Elena. (2021), An Empirical Analysis of Key Antecedents of Workforce Diversity on Job Performance in Nigeria. In: Journal of Economics and Business, Vol.4, No.1, 193-203.

ISSN 2615-3726

DOI: 10.31014/aior.1992.04.01.331

The online version of this article can be found at: https://www.asianinstituteofresearch.org/

Published by:

The Asian Institute of Research

The Journal of Economics and Business is an Open Access publication. It may be read, copied, and distributed free of charge according to the conditions of the Creative Commons Attribution 4.0 International license.

The Asian Institute of Research Journal of Economics and Business is a peer-reviewed International Journal. The journal covers scholarly articles in the fields of Economics and Business, which includes, but not limited to, Business Economics (Micro and Macro), Finance, Management, Marketing, Business Law, Entrepreneurship, Behavioral and Health Economics, Government Taxation and Regulations, Financial Markets, International Economics, Investment, and Economic Development. As the journal is Open Access, it ensures high visibility and the increase of citations for all research articles published. The Journal of Economics and Business aims to facilitate scholarly work on recent theoretical and practical aspects of Economics and Business. 


\title{
An Empirical Analysis of Key Antecedents of
}

\section{Workforce Diversity on Job Performance in Nigeria}

\author{
Helen Elena Jekelle ${ }^{1}$ \\ ${ }^{1}$ Faculty of Management and Social Sciences, Baze University, Abuja, Nigeria \\ Correspondence: Helen Elena Jekelle, Faculty of Management and Social Sciences, Baze University, Abuja, \\ Nigeria Tel: +2348037007137 / E-mail: helen.jekelle@bazeuniversity.edu.ng
}

\begin{abstract}
The study examined the effect of workforce diversity on job performance. The employees' diversity were conceptualised in terms of gender diversity, age diversity, and educational background diversity. The study was underpinned by the social identity theory as it examined such characteristics as gender, age and education. The social identity theory infers that employees have a tendency of classifying themselves based on groups in which they fit in. The study area was public sector in Abuja, Nigeria. The study adopted the quantitative research design whereby questionnaires were administered to the participants. A sample size of 208 participants were drawn from a population of 452 employees of the government agency in Abuja using Raosoft sampling size calculator. However, only 137 valid questionnaires were retrieved from the participants. Therefore, the data analysis was based on the valid retrieved questionnaires. Data analysis and hypotheses test was done using multiple regression analysis. The results showed a significant relationship between the dimensions of the explanatory variables (gender diversity, age diversity and educational background diversity) and the outcome variable (employee performance). The study also revealed that the combination of gender, age and education were the core elements that explained employee performance by 62.9 percent. In terms of individual contribution, the results indicate that educational background diversity contributed most to the variation of employee job performance while both age and gender also contributed significantly. The study therefore recommended that leadership of organisations need to focus more on diversity management in order to integrate the diverse characteristics of the workforce within the organisation.
\end{abstract}

Keywords: Age, Educational Background, Employee Performance, Gender, Workplace Diversity

\section{Introduction}

Effective workforce diversity management is a key evolving conception in the contemporary world. Numerous scholars have previously studied and examined this concept (e.g. Evans \& Henry 2007; Scott and Sims 2016; Sayers 2012; Leboho 2017 \& Robbins, 2009). Managing diversity means recognising people's variances and identifying these variances as valuable; as much as it improves effective management practices by stopping discrimination and encouraging inclusiveness. Furthermore, handling diversity encompasses leveraging and the 
usage of the cultural differences in people's skills, ideas and creativity to add to a common goal, and doing it in a way that gives the organisation a competitive edge (Morrison, 1992). Griffin \& Van Fleet (2014), defined three basics that contributed to organisations becoming more diverse. Such factors were identified as globalization, government legislation and judicial regulations and composition of the labour force.

Nowadays, organisational workstation is shifting at an enhanced pace and the transformation in the employees' demographics, increase of jobs in the economy, continuing growth of the globalization and requirement for efficient and effective collaboration have appeared as important driving force for the diversity in organisations. Griffin \& Moorhead (2014) indicated that having diverse workers entails that managers would recognise and handle the wide-ranging features that exist among the workers in the organisation.

Diversity antecedents or dimensions denote diverse traits, backgrounds and abilities of employees in an organisation. Rizwan, Khan, Nadeem, \& Abbas (2016) discussed how diversity dimensions management determines negative or positive employee performance in an organisation. The diversity antecedents consist of age, ethnicity, education backgrounds, social-economic status and difference in religions, among other characteristics. Diversity dimension management involves planning and implementing systems and practices aimed at accommodating diverse groups of people, maximizing the benefits and minimizing the adverse effects of having a diverse workers (Rizwan et al, 2016).

Employee performance significantly determines organisational success or failure since organisations work through people (Hameed \& Waheed, 2011). Therefore, employee performance discusses how well an employee discharges his or her duties and responsibilities, and creates an environment that improves the performance of the whole organization. The principles of employee performance include among others, employee relations, employee attitudes, employee turnover levels, creativity levels, and productivity levels. For the purpose of this study, three antecedents are examined. Such antecedents include gender, age and educational level. In order to become market leaders in this global business market, there is a major necessity for businesses to improve the performance of workers (Swaratsingh, 2015). Although the performance concept is very common in research, it is established and explained in various ways by different scholars.

\subsection{Statement of the Problem}

Globally, workforce diversity is perceived as a thought-provoking theme at the place of work and market. Organizations that support and attain an effective diverse workplace will appeal to and preserve quality workers and raise customer loyalty (Srivastava \& Agarwal, 2012). This diversity is viewed as an affirmative dynamism for employees' job performance by one sector, (Choi \& Rainey, 2010) whereas on the other term it is disapproving to employees' job performance. (Childs Jr, 2005) discusses how prior studies show that organizations with high levels of well-managed diversity are effective and direction-finding eventually creating corporate cultures that have new standpoints, pioneering competences, and fresh ideas which are necessary to survive. On the contrary, Choi and Rainey (2010) contended that workforce diversity produces conflicts and uncertainty in the workforce. Having high spot the potentials as well as flaws of workplace diversity, this study intends to examine some of the dimensions of workplace diversity which have not been given an adequate amount of research attention in exploring the variables that may influence employee performance such as gender, age and educational background diversities in the context of public sector in Nigeria generally and the organisation under study to be specific.

\subsection{Objectives of the Study}

i. To examine the relationship between Gender diversity and Employee Performance.

ii. To determine the association between Age diversity and Employee Performance.

iii. To assess the connection between Educational Background diversity and Employee Performance.

\section{Literature Review}

\subsection{Theoretical Review - Social Identity Theory}


Social identity is described as the ways that people's self-concepts are based on their membership in social groups. This theory further clarified that an employee work behaviour is defined by the inside principles of the group to which they belong. Accordingly, this directly influences the performance of the employee. This theory opens up the need for this study to investigate how the phenomenon of age diversity, gender diversity, and educational diversity contribute towards employee performance.

This study was underpinned by the social identity theory proposed by Trajfel \& Turner (1979) as it considers attributes such as gender, age and education which are being examined in this study. The social identity theory interprets that employees have a tendency of classifying themselves based on groups in which they fit in. Such group maybe be based on gender, age and education, amongst others. According to Trajfel \& Turner (1979), these groups are the foundation of egotism and self-confidence or agony and low self-confidence.

\subsection{Empirical Review and Hypotheses Development}

\section{Gender Diversity and Employee Performance}

Numerous researchers have examined the connection between gender diversity and employee performance. These scholars have diverse perceptions with regards to engaging women in organisations is advantageous to the organisation or otherwise. Campbell and Minguez-Vera (2008) contended that the existence and recognition of women may well positively encourage their performance and raise organisational performance as they bring extra viewpoints to decision-making. Oxelheim (2006) cites instances of extra viewpoints that women bring such as improved innovation capability, better global market insight and greater awareness of diverse customer needs. Conversely, several scholars have shown that the existence of women in organisations might not be of advantage, especially if legal, political and societal demands for gender equality influence their appointment. The conclusions of several meta-analyses point out that professional diversity might be treated as a double-edged sword: in some cases it may be advantageous, while in others it will be injurious, and in several circumstances it varies little in an organisation's functioning (Turek, 2017).

Even though with time women will be offered equal employment opportunities, a barrier still subsists between employer's views vis-a-vis gender diversity (Fernandez \& Lee, 2016). Sharma, (2015) discussed how there is no country so far has ever absolutely eliminated gender concerns such as discrimination, abuse and sexual harassment. Women are regarded as less skilled and less qualified for several jobs (Kundu, \& Mor, 2017). Prior works of research have recommended that any organisation that regards gender diversity as one of its main concern stands a chance to keep a capable workforce and increase its performance (Sharma, 2016; Emiko \& Eunmi, 2009). This can be underscored by the fact that women are considered as a very important economic unit of any society.

The rising general interest of organisational gender diversity has been recognised by both researchers and professionals and raised the question of whether organisational gender diversity affects the individual, group or organizational performance (Gupta, 2013). This explains to the extent of the performance of the level of analysis under scrutiny.

Brown, (2008) discussed how workforce diversity remains ineffectual if gender concerns are not first acknowledged. This assertion is in line with (Eagly \& Wood, 1991) study which stated that a mixed-gender achieved better than the same gender groups. Therefore the importance of both genders cannot be overemphasised, as each complements the other. Well-balanced structure of gender diversity in the organization may possibly make synergy effects which add to the workers performance. The reason may not be far-fetched as Bhatt, Gupta and Bhatta (2019) note that both male and female employees possess diverse skills and experiences which enhance sturdiness, unity, creativity, and innovation for effective and efficient individual or organization performance. Several scholarly works have revealed that gender diversity is positively related to employee and organisational performance (e.g. Frink, Robinson, Reithel, Arthur, Ammeter, Ferris, Kaplan, \& Morrisette (2003); McMillanCapehart (2006); Eugene, Lee, Tan, Tee, \& Yang (2011), Kyalo (2015), Ngao and Mwangi (2013), Selvaraj (2015) and Mwatumwa (2016). 
On the basis of the above discussions, the study hypothesised as follows:

$\mathrm{H}_{1}$ : There is a statistical significant relationship between gender diversity and job performance.

\section{Age Diversity and Employee Performance}

Age diversity is defined as the extent to which a group or organization is heterogeneous with respect to the age of its members (Li, Chu, Lam, \& Liao, 2011; Rabl \& Triana, 2014). It is defined as the variances in age distribution among workers within the organization (Kunze, 2013). Furthermore age diversity is categorized in the social category diversity for its high visibility and low job-relatedness (Pelled, 1996). Age, as a type of physical composition characteristic, is eagerly noticeable (Wegge, Roth, Neubach, Schmidt, \& Kanfer, 2008). Numerous scholarly works, show that age diversity has both plusses and minuses.

Age diversity has become an inevitable reality of life in numerous establishments (Kunze, Boehm, \& Bruch 2011). The highpoints of age diversity include problem-solving skills in the organization will be enhanced as diverse age brackets bring their skills to bear in tackling organizational issues. Also, age diversity will help in gaining access to the talented people in the organization. Age-diverse employees offers a host of various knowledge, values, perspectives, interpretations and preferences which are conditions for innovation (Richard \& Shelor, 2002). An admixture of young and old age bracket of employees with different knowledge and ideas can surge innovation as compared to having homogeneous employees (Backes-Gellner \& Veen, 2013). It has been alluded severally that the younger generation, otherwise known as the millennial are proficient when it comes to innovations and creativity. Therefore, the older generation will bring their experiences to bear while the younger employees will bring creativity and innovation to bear. At the end, the organization will benefit from these arrays of age diversity. Age diverse employees gives a vast multitude of numerous skills, intellectual styles, morals, and preferences that may result in increased productivity (Boehm \& Kunze 2015).

Lee and Kim (2020) contend that age diversity is expected to subvert the social assimilation of diverse workers as a result of strong social categorization-based processes. Against this backdrop, conditions considered by such lowquality relationships, workers feel less psychologically connected with the other members of their group and accordingly become indecisive to participate in communication and discussions (Milliken \& Martins, 1996; Zenger \& Lawrence, 1989). Poor communication, along with low-quality relationships at work, weakens successful work coordination (Smith, Smith, Olian, Sims, O'Bannon, \& Scully 1994). Also, Mwatumwa, (2016), discussed how age diversity causes issues related to communication and employees conflict. Against this backdrop, ineptitude of superiors to handle age diversity leads to conflict which lowers employees productivity (Mwatumwa, 2016). Furthermore, Barton and Nickerson (2004) show that groups with more diversity in age have been notably less productive. Similarly, Backes-Gellner and Veen (2009) argued that age heterogeneity can undesirably affect workers' productivity as a result of variances in values and preferences of divergent age groups (as cited in Odhiambo, Gachoka, \& Rambo, 2018). In the same vein, Elsaid (2012) showed that there is no relationship between age diversity and employee performance. Likewise, Kyalo and Gachunga (2015) and Selveraj (2015) showed that age diversity is not related to employee performance.

On the affirmative aspect of age diversity, Bohem and Kunze, (2015) stated how an age heterogeneous workforce can create vast amount of skills, intellectual styles, increases morals, that may result in increased productivity. This was buttressed by Backes-Gellner and Veen, (2009) study which stated that workers of diverse ages who work together in group enhance productivity than working alone since different people have different skills, perspectives, personality traits and a larger problem solving toolbox. This led to the conclusion of the studies conducted by Zhuwao, (2017) and Rizwan khan, Nadeem and Abbas, (2016) respectively which show positive relationship between age diversity and employee performance. Finally, a diverse age group of employees would therefore be more creative, dynamic and productive than a homogeneous age group (Williams \& O'Reilly, 1998; Zenger \& Lawrence, 1989).

On the basis of the above discussions, the following hypothesis has been framed. 
$\mathrm{H}_{2}$ : There is a statistical significant relationship between age diversity and job performance.

\section{Educational Background and Employee Performance}

Previous studies have shown that engaging employees from diverse educational echelons in the same workplace positively increases problem-solving, creativity and innovation (e.g. Pitts, Hicklin, Hawes, and Melton 2010). Bearing in mind workforce diversity benefits, management will work on increasing diversity to assuring innovation and creativity. Walster, Walster, and Berscheid (1978) stated that education support interactive participation and build constructive connections. Different educational backgrounds resulted in more task-related conflict among team members (Greer and Jehn, 2007). Accordingly, diversity in education levels can be associated with positive and negative effects on employee performance. Further, Webber and Donahue (2001) discussed how different educational backgrounds and levels appear to influence employee performance positively as it stimulates mutual learning with a wider range of cognitive resources and abilities. Educational diversity influences employees to work effectively with others to achieve organizational goals. The strategic objectives for human capital are to educate workers and get the most out of their knowledge, skills, and experience capabilities, in order to initiate organization value and improve its performance level (Hsiung and Wang, 2012), recognizing that knowledge creation is positively related to work performance (Ning, Chen, Yen, and Lun 2011). In fact, lower level for education and knowledge leads to poor efficiency. In furtherance to this, Eugene et al. (2011) recognised that there exists bias in educational diversity measure as it assesses diversity in workers who are exceedingly educated (Bachelor's degree and Postgraduate degree) and putting employees who are less educated in one group (e.g. Certificates and Diplomas).

Furthermore, Bamberger, Biron and Meshoulam (2014) noticed that informational diversity, such as education and functional areas, were positively related to actual work group performances, even though the relationship was mediated by task conflict. Additionally, Hambrick, Humphrey and Gupta (2015), stated that international experience and diverse educational background were positively related to firms" global, strategic postures among top management teams. In another study conducted by Elsaid (2012) with regards to Egyptian pharmaceutical industry showed that educational diversity was positively and significantly related to employee performance. Sequel to this results, Elsaid (2012) further clarified that more or balanced educational types may increase the likelihood of an organisation to benefit from increased creativity, innovation and improved employee performance. Additionally, in a study that focused on education sector in the context of Kenya conducted by Odhiambo (2014) discovered that educational diversity was significant in explaining a variation in employee performance. Similarly and in line with (Elsaid, 2012) study, Odhiambo (2014) found that having more diverse educational types in an organisation enhances problem-solving skills and decision-making amongst employees, accordingly resulting in improved employee performance.

Thus, the following hypothesis has been formulated:

$\mathrm{H}_{3}$ : There is a statistical significant relationship between educational diversity and employee job performance.

\section{RESEARCH METHODS}

\subsection{Research Design}

The study adopts a cross-sectional research design. According to Creswell (2013), definition of a cross-sectional research design was used to obtain a representative sample by taking a cross-section of the population of the organisation under study. Besides, since this study was intended at examine the relationship between the predictor variables (gender diversity, age diversity, and educational diversity) and the variable of interest (employee performance), a cross-sectional research design was more suitable. This is also in line with the study of Cohen, Manion and Morrison (2013) which specified that a cross-sectional research design is suitable for the descriptive functions that are related to correlational research. 


\subsection{Population and Sampling}

Bell and Waters (2014) define a population as a total group of individuals or units that are of interest to the researcher and individuals at which the outcomes of the study can be generalized. In this study, the target total population consisted of 452 employees of the organization under study. This comprises both male and females. Similarly, this study adopts the probability sampling technique where simple random sampling technique was applied to ensure that every employee in the population has an equal chance of being selected, thus improving the representativeness of the sample.

\subsection{Sample and Procedure}

The extant research utilized a sample of 208 workers drawn from a population of 452 from a public organisation in Abuja Nigeria that engage diverse workgroups, using a Raosoft Sample size calculator (www.raosoft.com). The participants were asked for their level of agreement or disagreement with a number of statements using a 5 - point Likert scale.

\section{DATA ANALYSIS}

\subsection{Response Rate}

A response rate is the number of people who answered the survey divided by the number of people in the sample. A total of two hundred and eight (208) sets of questionnaire were administered and one hundred and thirty-seven (137) were returned duly completed, representing $66 \%$ response rate as shown in Table 1.

According to Sekaran (2003), a response rate of $30 \%$ and above was regarded as being acceptable. With the response rate of $66 \%$ from the 208 randomly sampled participants, it is considered good for the course of this study.

Table 1: Questionnaire Return Rate

\begin{tabular}{lcc}
\hline Response Rate & Frequency & Percentage \\
\hline Retrieved & 137 & 66 \\
Not Returned & 71 & 34 \\
\hline Total & $\mathbf{2 0 8}$ & $\mathbf{1 0 0}$ \\
\hline
\end{tabular}

\subsection{Reliability Statistics}

A reliability statistics were done to measure the internal consistency of the variables. Its goal is to essentially test the internal consistencies and stability of the constructs by the use of the Cronbach Alpha Method. The reliability test is usually significant when Alpha value is 0.7 and above (Cronbach 1951). The value of Cronbach's Alpha was depicted in Table 2, where the reliability coefficient attained by all constructs was satisfactory as the combined alpha was 0.748 which is above 0.70 ; accordingly it showed high levels of reliability within the collected data of this research.

Table 2: Reliability Statistics

\begin{tabular}{ll}
\hline Cronbach's Alpha & N of Items \\
\hline .748 & 4 \\
\hline
\end{tabular}

\subsection{Correlation Analysis}

The correlation analysis helped to determine the relationship between the explanatory variables and the outcome variable. Pearson's correlation coefficient was used to show the direction, strength, and significance of the 
relationship. From the findings, it was found that there is positive association of gender diversity, age diversity, and educational background diversity, on employee job performance. In terms of strength, Cohen (1988) states that, if correlation (r) lies between $.10-.29$ then there is a low effect (low correlation); $r$ lies between $.30-.49$ has a medium effect (moderate correlation) and $r$ lies between $.50-.99$ has a large effect (strong correlation). Thus, gender, age and educational background diversities have correlations of .511, .372 and .760 respectively. Therefore, the constructs' correlation strength are strong correlation, moderate correlation and strong correlation respectively as shown in Table 3 .

Table 3: Correlations

\begin{tabular}{llllll}
\hline & & Emp_Perf & Gender & Age & Edu_Backg \\
\hline Emp_Perf & Pearson Correlation & 1 & $.511^{* *}$ & $.372^{* *}$ & $.760^{* *}$ \\
& Sig. (2-tailed) & & .000 & .000 & .000 \\
\multirow{5}{*}{ Gender } & $\mathrm{N}$ & 137 & 137 & 137 & 137 \\
& Pearson Correlation & $.511^{* *}$ & 1 & $.228^{* *}$ & $.491^{* *}$ \\
& Sig. (2-tailed) & .000 & & .007 & .000 \\
Age & $\mathrm{N}$ & 137 & 137 & 137 & 137 \\
& Pearson Correlation & $.372^{* *}$ & $.228^{* *}$ & 1 & $.264^{* *}$ \\
& Sig. (2-tailed) & .000 & .007 & & .002 \\
Edu_Backg & 137 & 137 & 137 & 137 \\
& $\mathrm{~N}$ & $.760^{* *}$ & $.491^{* *}$ & $.264^{* *}$ & 1 \\
& Pearson Correlation & .000 & .000 & .002 & \\
& Sig. (2-tailed) & 137 & 137 & 137 & 137 \\
& $\mathrm{~N}$ & & &
\end{tabular}

**. Correlation is significant at the 0.01 level (2-tailed).

\subsection{Hypothesis Testing}

To test the research hypotheses, multiple linear regressions were used to examine the association between more than two independents variables and one dependent variable (Hair, Black, Babin \& Anderson 2010). Regression analysis was conducted to test the formulated hypotheses in this study. Multiple linear regression analysis was implemented to assess whether the predictor variables (gender diversity, age diversity, and educational background diversity predict the variable of interest (employee job performance).

Table 4: Model Summary ${ }^{\mathrm{b}}$

\begin{tabular}{llllll}
\hline & & & Adjusted & R & Std. Error of the \\
Model & $\mathrm{R}$ & $\mathrm{R}$ Square & Square & Estimate & Durbin-Watson \\
1 & $.793^{\mathrm{a}}$ & .629 & .621 & 1.733 & 1.721 \\
\hline
\end{tabular}

a. Predictors: (Constant), Edu_Backg, Age, Gender

b. Dependent Variable: Emp_Perf

To determine the extent to which the explanatory variables explain variation of employee job performance, the model summary was worked out. The results in Table 4 show that the coefficient of determination or R-square value is 0.629 , thus meaning that gender, age and educational diversity can explain $62.9 \%$ of the outcome variable (employee performance). However, it still leaves out 37.1\% (100\%, - 62.9\%) unexplained in this research. This implies that there are other additional important variables that have not been considered in this study and are vital in explaining variation in employee job performance.

Table 5: ANOVA $^{\mathrm{a}}$

\begin{tabular}{lllllll}
\hline Model & & Sum of Squares & df & Mean Square & F & Sig. \\
\hline 1 & Regression & 677.396 & 3 & 225.799 & 75.162 & $.000^{\mathrm{b}}$ \\
& Residual & 399.553 & 133 & 3.004 & & \\
& Total & 1076.949 & 136 & & & \\
\hline
\end{tabular}

a. Dependent Variable: Emp_Perf

b. Predictors: (Constant), Edu_Backg, Age, Gender 
To test the statistical significance of the regression model on whether it is a good predictor of the variable of interest (employee job performance), Analysis of variance (ANOVA) was implemented. Accordingly, the results in Table 5 show that the model is a good predictor of the relationship between the independent variables (gender diversity, age diversity and educational diversity) and the outcome variable (employee performance) $(\mathrm{F}=75.162$; $\mathrm{p}=0.000$ ). This means that the predictor variables (gender diversity, age diversity and educational diversity) are significant in explaining the variance in the dependent variable (employee job performance).

Table 6: Coefficients ${ }^{\mathrm{a}}$

\begin{tabular}{|c|c|c|c|c|c|c|c|c|}
\hline \multirow[b]{2}{*}{ Model } & & \multicolumn{2}{|c|}{$\begin{array}{l}\text { Unstandardized } \\
\text { Coefficients }\end{array}$} & \multirow{2}{*}{$\begin{array}{c}\text { Standardized } \\
\text { Coefficients } \\
\text { Beta } \\
\end{array}$} & \multirow[b]{2}{*}{$\mathrm{t}$} & \multirow[b]{2}{*}{ Sig. } & \multicolumn{2}{|c|}{$\begin{array}{l}\text { Collinearity } \\
\text { Statistics }\end{array}$} \\
\hline & & B & Std. Error & & & & Tolerance & VIF \\
\hline 1 & (Constant) & 4.671 & 1.316 & & 3.549 & .001 & & \\
\hline & Gender & . 128 & .049 & .160 & 2.629 & .010 & .749 & 1.335 \\
\hline & Age & .144 & .048 & .167 & 3.026 & .003 & .918 & 1.090 \\
\hline & Edu_Backg & .536 & .052 & .638 & 10.351 & .000 & .735 & 1.361 \\
\hline
\end{tabular}

a. Dependent Variable: Emp_Perf

Here in the coefficient Table 6 , the standardized beta value would be taken into consideration. When analyzing the three independent variables, the significance values need to be less than 0.05 to accept as significant and the value of beta is positive which states that the impact is positive. To compare which explanatory variable between gender diversity, age diversity and educational diversity contributes most to the variation of employee job performance, beta standardized coefficients were used. Thus, the results in Table 6 indicate that educational background diversity contributed most to the variation of employee job performance $(\beta=0.638 ; p=0.000)$, while age and gender diversity equally contributed $\beta=0.167 ; p=0.003$ and $\beta=0.160 ; p=0.010$ respectively. The high contribution of educational background diversity could be largely due to the cross-functional and multidimensional learning experiences that usually characterized both formal and informal education and learning which defines and guides job performance in the workplace; while the two variables appears as two most potent channels and drivers of learning diversity.

In the equation, $\mathrm{Y}=\beta 0+\beta 1 \mathrm{X} 1+\beta 2 \mathrm{X} 2+\beta 3 \mathrm{X} 3+€$

Emp_Perf $=4.671+.128 \mathrm{Gender}+.144 \mathrm{Age}+.536 \mathrm{Edu} \_$Backg

\section{Discussion, Conclusion and Recommendations}

This study examined the effect of workforce diversity on job performance. The proxies of employees' diversity were assessed in terms of gender diversity, age diversity, and educational background diversity. With regards to the results acquired by the regression analysis, it was discovered that there is positive and significant impact of workforce diversity on employee performance. The findings showed that there is positive and significant relationship between gender diversity, age diversity and job performance. The findings of this research work affirmed that increasing age diversity is positively related to employee performance. The results of the analysis indicated that there is significant and positive relationship between educational background diversity and employee performance. Prior scholarly works had shown that the same conclusion stating that gender diversity, age diversity and educational diversity were positively and significantly related to employee job performance (e.g. Mwatumwa (2016); Ngao and Mwangi (2013) - for gender; Zhuwao, (2017) and Rizwan khan, Nadeem and Abbas, (2016) for age diversity; and lastly for education level, the findings are in consonance with Hsiung and Wang, (2012) and Ning, Chen, Yen, and Lun (2011)).

On the basis of the findings, the study concluded that the dimensions of work diversity have significant effect on employee performance in the organisation under study. Gender, age, and education diversities are vital constituents of employees' activities in the work place that enrich employee performance. The study revealed that the 
combination of gender, age and education were the core elements that explained employee performance by 62.9 percent. The study has presented an empirical evidence that there is a significant relationship between workplace diversity dimensions - gender, age, and education and employee performance of the organisation under study.

Therefore, this study recommended that leadership of organisations needs to focus more on diversity management in order to integrate the diverse characteristics of the workforce within the organisation. It was also recommended that organisational leaders should formulate policies on equal employment, irrespective of their gender, age, and educational background in order to bring to the fore, creativity and innovation to the organisation by an admixture of diverse workforce irrespective of cadre in the organisational ladder.

\section{References}

Backes-Gellner, U., \& Veen, S. (2009). The impact of aging and age diversity on company performance. ISU Working Paper 78, University of Zurich. Post print available at: http://www.zora.uzh.ch.

Bamberger, P. A., Biron, M., \& Meshoulam, I. (2014). Human resource strategy: Formulation, implementation, and impact. London, UK: Routledge.

Bell, J., \& Waters, S. (2014). Doing your research Project: A guide for first-time researchers (6th ed.). New York, USA: McGraw-Hill Education.

Bhatt, S.P., Gupta, A.K. \& Bhatta (2019). Does Workforce Diversity Influence Employee Performance? An Empirical Analysis of Nepali Civil Service. IUJ Journal of Management Vol. 7, No. 2, Dec. 2019

Boehm, S. A., \& Kunze, F. (2015). Age diversity and age climate in the workplace. In Aging workers and the employee-employer relationship (pp. 33-55). Springer, Cham.

Brown, S. L. (2008). Diversity in the workplace: A study of gender, race, age, and salary level. Capella University.

Campbell, K., \& Minguez-Vera, A. (2008). Gender diversity in the boardroom and firm financial performance. Journal of Business Ethics, 83(3), 435-451. https://doi. org/10.1007/s10551-007-9630-y

Childs Jr, J. (2005). Managing workforce diversity at IBM: A global HR topic that has arrived. Human Resource Management, 44(1), 73-77.

Choi, S., \& Rainey, H. G. (2010). Managing diversity in US federal agencies: Effects of diversity and diversity management on employee perceptions of organizational performance. Public Administration Review, $70(1), 109-121$.

Cohen, J. (1988). Statistical power analysis for the behavioural sciences (2nd ed.). Hillsdale, New Jersey: Lawrence Erlbaum.

Cohen, L., Manion, L., \& Morrison, K. (2013). Research methods in education. Abington, USA: Routledge Publications.

Creswell, J. W. (2013). Research design: qualitative, quantitative, and mixed methods approach. housand Oaks, USA: Sage publications.

Eagly, A. H., \& Wood, W. (1991). Explaining sex differences in social behaviour: A meta-analytic perspective. Personality and social psychology bulletin, 17(3), 306-315.

Elsaid, A. M. (2012). The Effects of cross cultural workforce diversity on employee performance in Egyptian pharmaceutical organizations. Business and Management Research, 1(4), 162-180.

Emiko, M., \& Eunmi, C. (2009). Diversity management and the effects on employees' organisational commitment: Evidence from Japan and Korea. Journal of World Business, 44, 31-40. https://doi.org/10.1016/j.jwb.2008.03.018

Eugene, C., Lee, K., Tan. S., Tee, S. \& Yang, P. (2011). Effects of workforce diversity on employee performance. Journal of Social Science, 20(1), 173-198.

Evans, A. J., \& Henry, O. (2007). Critical Review of Literature on Workforce Diversity. African Journal of Business Management, 072-076.

Fernandez, S., \& Lee, H. (2016). The transformation of the South African Public Service: Exploring the impact of racial and gender representation on organisational effectiveness. The Journal of Modern African Studies, 54(1), 91-116. https://doi.org/10.1017/S0022278X15000816

Frink, D. D., Robinson, R. K., Reithel, B., Arthur, M. M., Ammeter, A. P., Ferris, G. R., Kaplan, D. M., \& Morrisette, H. S. (2003). Gender demography and organization performance: A two- study investigation with convergence. Group \& Organization Management, 28(1), 127-147.

George, D., \& Mallery, P. (2003). SPSS for Windows step by step: A simple guide and reference. 11.0 update (4thed.). Boston: Allyn \& Bacon. 
Greer, L. L., \& Jehn, K. A. (2007). Chapter 2 the pivotal role of negative affect in understanding the effects of process conflict on group performance. In Affect and Groups (pp. 21-43). Emerald Group Publishing Limited.

Griffin, R. W., \& Van Fleet, D. D. (2014). Management Skills: Assessment and Development. U.S.A.: South Western Cengage Learning.

Gupta, R. (2013). Workforce diversity and organizational performance. International Journal of Business and Management Invention, 2(6), 36-41.

Hair, J.F., Black, W.C., Babin, B.J., and Anderson, R.E. 2010. Multivariate data analysis: A global perspective. New Jersey, Pearson Prentice Hall. 5th edition.

Hambrick, D. C., Humphrey, S. E., \& Gupta, A. (2015). Structural interdependence within top management teams: A key moderator of upper echelons predictions. Strategic Management Journal, 36(3), 449-461.

Hameed, A., \& Waheed, A. (2011). Employee development and its effect on employee performance: A conceptual framework. International Journal of Business and Social Science, 2 (13), 224- 229.

Hsiung, H.H., and Wang, J. 2012. Value creation potential of intellectual capital in the digital content industry. Investment Management and Financial Innovations 9(2): 81-90. http://www.raosoft.com/samplesize.html

Kundu, S. C., \& Mor, A. (2017). Workforce diversity and organisational performance: A study of IT industry in India. Employee Relations, 39(2), 160-183. https://doi. org/10.1108/ER-06-2015-0114

Kunze, F., Boehm, S. and Bruch, H. (2011). 'Age diversity, age discrimination, and performance consequences a cross organizational study'. Journal of Organizational Behaviour, 32, 264-90.

Kunze, F., Boehm, S., and Bruch, H. (2013). Organizational Performance Consequences of Age Diversity: Inspecting the Role of Diversity-Friendly HR Policies and Top Managers' Negative Age Stereotypes. In: Journal of Management Studies. 50(3), pp. 413-442. ISSN 0022-2380. E-ISSN 1467-6486.

Kyalo, J. M. K., \& Gachunga, H. (2015). Effect of diversity in workplace on employee performance in the banking industry in Kenya. Strategic Journal of Business \& Change Management, 2(2).

Leboho, M. (2017). The relationship between gender diversity and corporate profitability: The top 100 companies on the JSE ltd. Masters research, University of Johannesburg, South Africa.

Lee, H. W., \& Kim, E. (2020). Workforce diversity and firm performance: Relational coordination as a mediator and structural empowerment and multisource feedback as moderators. Human Resource Management, $59(1), 5-23$.

Li, J., Chu, C. W. L., Lam, K. C., \& Liao, S. (2011). Age diversity and firm performance in an emerging economy: Implications for cross-cultural human resource management. Human Resource Management, 50(2), 247-270.

Milliken, F. J., \& Martins, L. L. (1996). Searching for common threads: Understanding the multiple effects of diversity in organizational groups. Academy of Management Review, 21(2), 402-433.

McMillan-Capehart, A. (2006). Heterogeneity or Homogeneity. Performance Improvement Quarterly, 19(1), 8398.

Morrison, A. M. (1992). The New Leaders: Guidelines on Leadership Diversity in America. Jossey-Bass Management Series. Jossey-Bass, Inc., Publishers, 350 Sansome Street, San Francisco, CA 94104.

Mwatumwa, A. S. (2016). Effect of workforce diversity on employee work performance: A study of the county government of Mombasa. Masters dissertation submitted to University of Mombasa, Kenya.

Ngao, E., \& Mwangi, C. (2013). Effects of managing gender of employees in enhancing organizational performance. A case study of Kenya ports authority. European Journal of Business and Management, $5(21), 50-62$.

Ning, Y.T., Chen, C.H., Yen, L.S., and Lun, T.C. (2011). Knowledge creation and intellectual capital on securities investment services. African Journal of Business Management, 5(3): 924-933.

Odhiambo, O. W. (2014). Workforce diversity and its effects on employee performance: a case of Mbita sub county Homa-Bay County in Kenya (Doctoral dissertation, Moi University).

Oxelheim, L. (2006). A Nordic perspective of corporate board diversity. Norway: Nordic Innovation Centre.

Pelled, L. H. (1996). Demographic diversity, conflict, and work group outcomes: An intervening process theory. Organization Science, 7(6), 615-631.

Pitts, D. W., Hicklin, A. K., Hawes, D. P., \& Melton, E. (2010). What drives the implementation of diversity management programs? Evidence from public organizations. Journal of Public Administration Research and Theory, mup044.

Rabl, T. \& Triana, M. (2014) Organizational value for age diversity and potential applicants' organizational attraction: Individual attitudes matter. Journal of Business Ethics, 121, 403-417.10.1007/s10551-013-17298.

Rizwan, M., Khan, M., Nadeem, B., \& Abbas, Q. (2016). The impact of workforce diversity towards employee performance: Evidence from banking sector of Pakistan. American Journal of Marketing Research, 2 (2), 53- 60 . 
Robbins. (2009). The equal opportunities handbook: How to recognize diversity, encourage fairness and promote anti-discriminatory practice. In L. Roberson \& C. T. Kuluk (Eds.). Stereotype Threat at Work, 136-154. London: Kogan Page.

Sayers, J. (2012). Managing Diversity. Retrieved October 4, 2016, from www.bookboon.com/en/managingdiversity-ebook

Scott, C. L., \& Sims, J. D. (2016). Developing Workforce Diversity Programs, Curriculum, and Degrees in Higher Education. USA: Information Science Reference.

Sekaran U. 2003. Research Methods for Business: A Skill Building Approach. 4th edn. John Wiley: Hoboken, NJ.

Selvaraj, P. C. (2015). The effects of work Force diversity on employee performance in Singapore organisations. International Journal of Business Administration, 6(2), 17.

Sharma, A. (2015). Managing diversity and equality in the workplace. Cogent Business and Management, 3, 114.

Sharma, A. (2016). Managing diversity and equality in the workplace. Cogent Business \& Management, 3(1), 121-136.

Smith, K. G., Smith, K. A., Olian, J. D., Sims, H. P., Jr., O'Bannon, D. P., \& Scully, J. A. (1994).Top management team demography and process: The role of social integration and communication. Administrative Science Quarterly, 39, 412-438.

Srivastava, E., \& Agarwal, N. (2012). The emerging challenges in HRM. International journal of scientific \& technology research, 1(6), 46-48.

Swaratsingh, K. (2015). Enhancing workplace productivity and competitiveness in Trinidad and Tobago through ICT adoption (Doctoral dissertation, Walden University).

Trajfel \& Turner, J.C (1979). Social comparison and group interest in group favouritism. European Journal of Social Psychology, 63(1), 781-796.

Turek, D. (2017). What Do We Know about the Effects of Diversity Management? A Meta-analysis. Zeszyty Naukowe Uniwersytetu Ekonomicznego w Krakowie, 964(4), 5-25.

Vroom, V. H. (1964). Work and motivation. New York, NY: Wiley \& Sons.

Walster, E., Walster, G. W., \& Berscheid, E. (1978). Equity: Theory and research.

Webber, S. S., \& Donahue, L. M. (2001). Impact of highly and less job-related diversity on work group cohesion and performance: A meta-analysis. Journal of management, 27(2), 141-162.

Wegge, J., Roth, C., Neubach, B., Schmidt, K.-H., \& Kanfer, R. (2008). Age and gender diversity as determinants of performance and health in a public organization: The role of task complexity and group size. Journal of Applied Psychology, 93(6), 1301-1313.

Williams, K. Y., \& O'Reilly, C. A. (1998). Demography and diversity in organizations: A review of 40 years of research. Research in Organizational Behaviour, 20 (20), 77-140.

Wittenbaum, G. M., \& Stasser, G. (1996). Management of information in small groups.

Zenger, T. R., \& Lawrence, B. S. (1989). Organizational demography: The differential effects of age and tenure distributions on technical communication. Academy of Management Journal, 32(2), 353-376.

Zhuwao, S. (2017). Workforce diversity and its effects on employee performance in Higher Education Institution in South Africa: a case study of University of Venda. 